\title{
FROM THERE TO HERE, THE DAS CONTAS RIVER DRAWING... ITS LANDSCAPES
}

\author{
CHIAPETTI, Rita Jaqueline Nogueira; ${ }^{*}$
}

(a) DSc in Geography, Lecteur University State of Santa Cruz (UESC). http://lattes.cnpq.br/3991631209906844

\section{(*) CORRESPONDING AUTHOR}

Address: UESC, Rodovia Jorge Amado, km 16, CEP: 45662900, Ilhéus (BA), Brasil. Telefone: (+ 5573$) 36805112$ E-mail: jaque@uesc.br

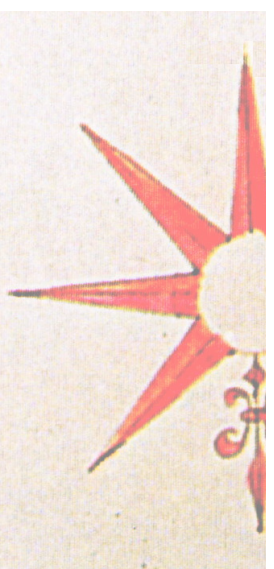

\section{ABSTRACT}

The inspiration for writing this poetic essay was the pictorial-poetic image of the Das Contas River, representing the landscapes drawn along its banks. The essay aims to make a geographical reading of this waterway, interpreting and analyzing its landscape, based on its pictorial representation. To and fro... from the source to the mouth ... or from west to east, the Das Contas River flows approximately $500 \mathrm{~km}$ in the Bahia, connecting three biomes: the Cerrado, the Caatinga and the Atlantic Forest. It is born on the Tromba mountain range in the municipality of Piatã, and flows into the Atlantic Ocean, in front of the city of Itacaré, in southern Bahia. These images were analyzed using the phenomenological method, relating their reading and interpretation to the understanding of the landscape as perceived by us and lived by the people who sail on its waters and inhabit its banks, going beyond reality to the meaning of the river, its essence. The main landscapes represented range from the green mountains of the Chapada Diamantina, passing through the yellow Caatinga of Bahia's hinterlands to the green landscape of the Cabruca Forests (an agro forestry system intercropping cocoa with the forest), in the Atlantic Forest on the south coast of Bahia.

Keywords: Das Contas River, pictorial-poetic image, landscape.

\section{RESUMO/ RESUMEN}

\section{DE LÁ PARA CÁ, O RIO DAS CONTAS DESENHANDO... SUAS PAISAGENS}

A inspiração para a escrita desde ensaio poético foi a imagem pictórico-poética do rio das Contas, representando as paisagens desenhadas ao longo de suas margens. Objetiva fazer uma leitura geográfica dessa estrada hídrica, em direção à interpretação e análise da sua paisagem, a partir da sua representação pictórica. De lá para cá... da nascente à foz... ou de oeste a leste, o rio das Contas percorre, aproximadamente, 500 $\mathrm{km}$ na Bahia, conectando três biomas: Cerrado, Caatinga e Mata Atlântica. Nasce na serra do Tromba, em Piatã, e deságua no Oceano Atlântico, na cidade de Itacaré, no sul da Bahia. A análise dessa imagem seguiu os caminhos da fenomenologia, relacionando sua leitura e interpretação à compreensão das paisagens percebidas por nós e vividas pelas pessoas a navegarem suas águas e habitarem suas margens, indo além da realidade ao sentido do rio, sua essência. As principais paisagens representadas vão do verde das montanhas da Chapada Diamantina, passando pela caatinga amarela do sertão baiano, até a paisagem novamente verde da cabruca (cultivo do cacau consorciado com floresta), na Mata Atlântica no litoral sul baiano.

Palavras-chave: Rio das Contas; Imagem pictórico-poética; Paisagem.

\section{DE ALLÁ PARA ACÁ, EL RÍO DE CUENTAS DIBUJANDO... SUS PAISAJES}

La fuente de inspiración para escribir este ensayo poético fue la imagen pictórico-poética del Río de Cuentas, representando los paisajes dibujados a lo largo de sus orillas. El ensayo quiere hacer una lectura geográfica de esta ruta fluvial, hacia la interpretación y el análisis de sus paisajes, con base en su representación pictórica. De allá para acá... desde la naciente a la boca... o de oeste a este, el Río de Cuentas corre aproximadamente $500 \mathrm{~km}$ en la Bahía, conectando tres biomas: Cerrado, Caatinga y Mata Atlántica. Nace en Tromba, municipio de Piatã, Chapada Diamantina y desemboca en el Océano Atlántico, en la ciudad de Itacaré, sur de Bahía. El análisis de esta imagen fue hecha por medio de la fenomenología, relacionando la lectura e interpretación a la comprensión del paisaje percibido por nosotros y vivida por las personas que navegan por sus aguas y habitan en sus orillas, yendo más allá de la realidad hacia el significado del río, su esencia. Los principales paisajes van desde las verdes montañas de la Chapada Diamantina, atravesando la caatinga amarilla del semiárido Bahiano y retornando a un paisaje verde de bosque de cabruca (cultivo intercalado de cacao con bosque), en la Mata Atlántica en la costa sur de Bahía.

Palabras clave: Río de Cuentas, Imagen pictórico-poética, Paisaje. 


\section{INTRODUCTION}

The river tells man what he must do.

And man follows the river's orders. Otherwise, he succumbs (MELLO, 1987, p. 24).

According to the epigraph that begins this text, we must obey the river in order not to perish. So, following its order, in this text we navigate with our rudder facing the course of the (not always) torrential stream of the Das Contas River, having as our artistic support its pictorial-poetic image, as a representation of its landscape from there to here, that is, from the source to the mouth or from west to east. The purpose of this text is to make a geographical reading of the Das Contas River and to interpret and analyze its landscape from its pictorial representation.

We consider the waters of the Das Contas River rising on the summit of a mountain to give life to the people of its river basin, as rivers are for the brilliant artist-painter-scientist Leonardo Da Vinci, as in his paintings rivers represent the veins of the human body or veins of the Earth, making an analogy between the human body and the Earth's body. In this conception, rivers are more than simply water courses... they are life-givers, they are the Earth's veins, as Bachelard (2002, p. 65) thinks water: "[...] must command the earth. It is the Earth's blood. The life of the Earth. It is water that will drag the whole landscape to its own destiny". For the same author, the waters of the rivers, maternal waters, female waters are compared with a mother's love, immensely large, eternal and projected into infinity...

Water seduces us with its vital energy, awakening poetic images translated into aquatic symbolism. For Dardel (2011), the waters that emerge from rivers are life-giving waters, the ultimate symbol of life or a fountain of youth. Oliveira (2002) corroborates the statement about water as a symbol of life, making itself present to guarantee our biological life. For Chevalier and Gheerbrant (2007, p. 781): “[...] the river always symbolizes human existence and the course of life, with the succession of desires, feelings and intentions [...]".

A river is connected to its flow ... to the continuous movement of its stream of water, leading its waters to its destination ... which may be another river, a lake or the sea. The same banks that separate, even if it is only an apparent separation, can unite, delimit, separate or join, depending on people or our perception. This is the Das Contas River, a river that flows through the lands of Bahia... a vein that rises delicately like a stream of water on a mountain in the Chapada Diamantina, gaining more water on the surface, running in depressions and plateaus for more than $500 \mathrm{~km}$ from west to east, donating life or living conditions to the people who made and make our Bahia, until reaching its mouth in the south coast of Bahia, where the mangrove swamps and mudflats on its banks are essential to human life.

According to Chiapetti (2009), along its length, the Das Contas River connects three biomes: the Cerrado in the Chapada Diamantina (young river), the Caatinga in the sertão (mature river) and the Atlantic Forest in the area closest to the coast (mature and old river). In the first biome (Cerrado), the river flows for approximately $135 \mathrm{~km}$, in the second (Caatinga) for about $230 \mathrm{~km}$ and in the third biome (Atlantic Forest) for around $125 \mathrm{~km}$. It is difficult to estimate its width and depth throughout the course, but in the Atlantic Forest it is approximately $30 \mathrm{~m}$ from one margin to the other, with an estimated depth of $3 \mathrm{~m}$. In the section near its mouth it is around $200 \mathrm{~m}$ wide, with a good depth, although at low tide it displays many sandbars (deposits of sand in the form of cords that cause the silting of its bed).

The main tributaries that give their waters to the Das Contas River on the right bank are: Brumado, Gavião, Peixe and Gongogi, and on the left bank: Sincorá, Ourives, Laço, Jacaré, Jequiezinho and Oricó. It is perennial for its entire route but is not very fast-flowing along all its extension. Its flow is approximately $1.76 \mathrm{~m} 3 / \mathrm{s}$ along the young course, reaching about $100 \mathrm{~m} 3 / \mathrm{s}$ on the old course. Irregular rainfall along its course and during the year cause a marked variability in its streamflow, 
mainly due to the rigors of the semi-arid climate of the sertão in Bahia, where there is water loss by evaporation, contributing considerably to the decrease of the water volume in this section, since most of its tributaries are intermittent in the Cerrado and Caatinga biomes. However, within the Atlantic Forest its water volume increases due to the generosity of its tributaries and the amount of rain that falls regularly during almost the whole year in this biome (CHIAPETTI, 2009).

The Das Contas River is not just one of the five main rivers in Bahia, which is born in an oasis within its semi-arid region, that is, the Chapada Diamantina, flowing through the sertão without its waters drying out and providing the subsistence of the population of the sertão... that navigates the forest telling the sertão's secrets... before finally emptying into the sea. It is also a historic river, like all the great rivers that are references to society. In ancient times, boats loaded with food navigated its waters ensuring the survival of many people in the villages on its banks. It also served as a guide for Europeans penetrating the continent, looking for riches in the Brazilian subsoil and taking them out of the country (how sad!).

In the waters of the Das Contas River people draw their life stories, "their geographies", and so it draws landscapes on its banks, full of life, that "sing and tell" its way through the lands of Bahia. Inspired by Bachelard (2002, p. 17), for whom: "[...] the language of waters is a direct poetic reality $[\ldots]$ ", in the next item we present the pictorial-poetic image of the river, which was designed/drawn to illuminate its course, while illuminating/illustrating our text, since water gives movement to the senses and expressions, which are revealed through our poetic language.

\section{THE POETRY OF THE DAS CONTAS RIVER: FROM THE CHAPADA DIAMANTINA TO THE ATLANTIC OCEAN}

It is important to clarify that we have analyzed the pictorial-poetic image of the Das Contas River through the paths of phenomenology, relating its reading and interpretation to the understanding of the landscapes perceived by us and lived by the people who navigate its waters and inhabit its banks, going beyond reality to the meaning of the river, its essence. Our phenomenological view, as well as Lessa's (2007), considers materiality as a result of the presentiment of values and signs, that is, landscapes are configured as essences that characterize and qualify the spatial identity of places.

According to Bachelard (2005), only phenomenology, that is, the consideration of the beginning of an image in an individual consciousness can help us to reconstitute the subjectivity of the image and measure its amplitude, force and the meaning of its trans-subjectivity. For Bachelard, the phenomenological method allows the force of our experience in the vision of the image, not being a purely descriptive method but rather, it appropriates the strength of the individual experience for the description.

We use phenomenology, therefore, in an attempt to explain our experience/understanding of the poetics of the river (in the image), the symbols, their landscapes and finally, the meaning of the river, from what we perceive, know and recreate. The meaning of the river is its essence and, according to Holzer (1997), these essences are as many as the meanings we can produce through perception, thought, memory and imagination, giving these interpretations universal, inter-subjective and absolute marks. We also use phenomenology with the intention of tracing another writing of the river, such as Gratão (2007a), referring to Dardel when he deals with existence and geographical reality, by the poetic approach that makes Geography.

Thus, we proceeded to present the pictorial-poetic image of the Das Contas River, signed by the artist-architect Bruno Harry Ceccato, who, at our request composed the images of a doctoral thesis on the geographic perception of such a river (CHIAPETTI, 2009). This image represents the 
entire course of a river in Bahia, which flows from a mountain range of the Chapada Diamantina, in the municipality of Piatã (from there) and flows into the Atlantic Ocean in Itacaré (to here), a city in southern Brazil (Figure 1).

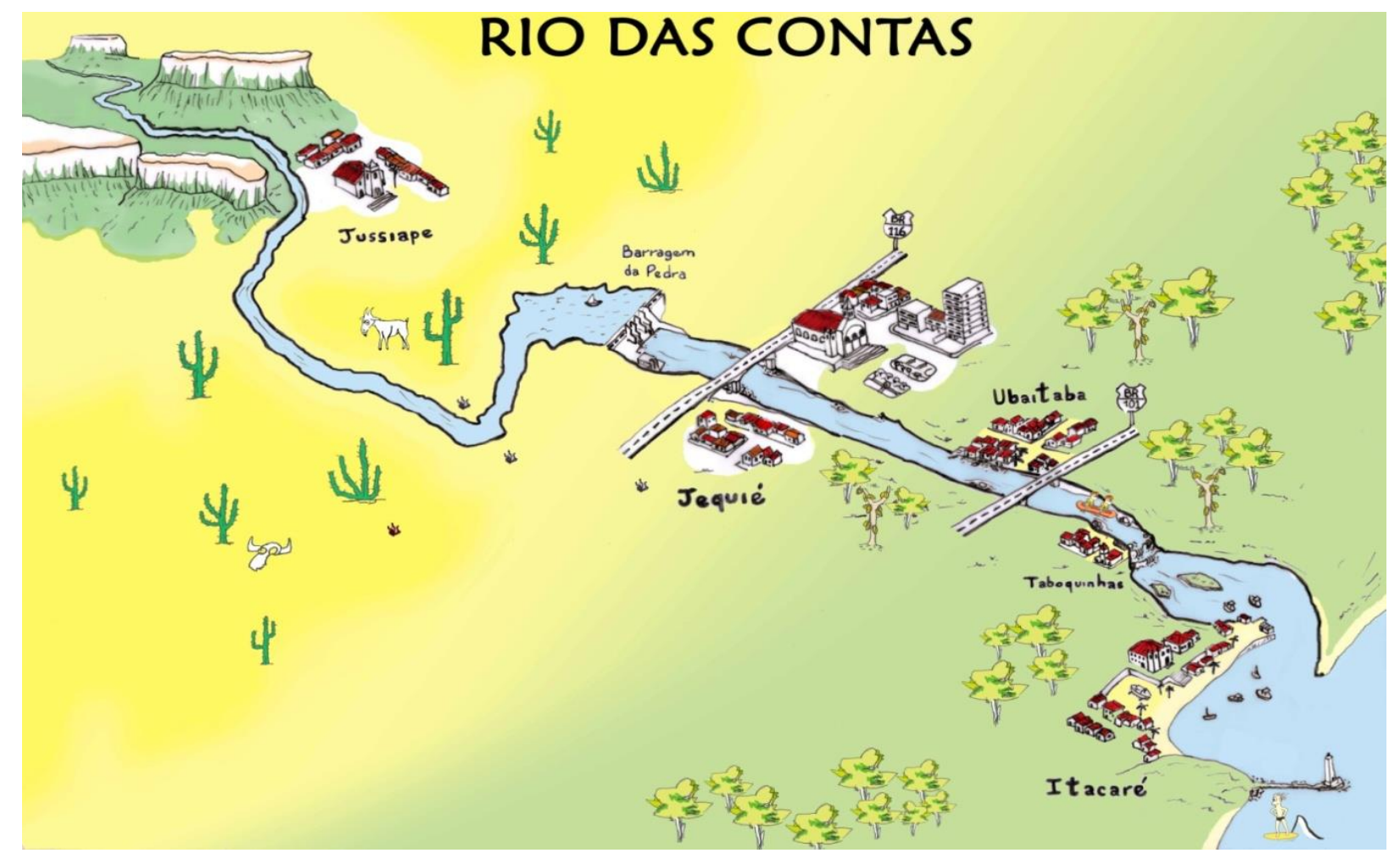

Figure 1 - Pictorial-poetic image of the Das Contas River, Bahia. Source: Chiapetti (2009, p. 72). From Bruno Harry Ceccato

It is important to emphasize that our reading of the image cannot be taken as an absolute truth because just like a written text it may have insufficiencies and limitations, since it is made from our perception and cognition. When this image was elaborated, its main purpose was to represent the Das Contas River within the Atlantic Forest, the main focus of our research at that time, so perhaps it has more details in its final section: "In the beauty of the place, Das Contas River going... to the sea" (CHIAPETTI, 2009).

But why are we calling this pictorial drawing a poetic image? Because when we asked Bruno to create it, we showed him some images of the Das Contas River and we described it from the source to the mouth, talking about it as if it were a person, a friend, so great has been our intimacy with this river, since we decided to study it. Like Gratão (2002, 2007a), we find ourselves with the river, we feel a water geography that is born of the deep affective bond with it: hydric topophilia or hydrophilia!

So Bruno imagined the river materially and poetically and created this drawing/image, as if he were navigating its waters... experiencing every bank, every landscape, every moment, every curve of the river. His imaginary was seduced by our imagination, which led his hand to draw the river and its banks bathed in life all along its route! After all, according to Bachelard (2005, p. 2): "The poetic image emerges in consciousness as a direct product of the heart, the soul, the being of man taken in its totality". However, it also has matter. Water is matter and imagination, it wraps dreams, and it is a source of poetic inspiration, as manifest in human images and symbols and in their actions (GRATÃO, 2007b).

Looking at an image and representing it pictorially, in a way, is rather easy for a draftsman-artist; but only for a person who thinks about and feels the world with great sensitivity (with heart 
and soul). We imagine that it is difficult to give a sense of understanding and to be able to communicate one's vision, so as to interpret what a humanist geographer thinks, charmed by the object of study. In this sense, we can affirm that the architect-artist's gaze took place through the "eyes of the mind" because it came from his perception and imagination in relation to the images we gave him, from the aspects of the landscapes of these images, seeking the elements that represent them. The imagination surpasses reality, it sees the invisible, it goes to the bottom of things... the image can only be captured in the measure that it has its entire being in the imagination (CHIAPETTI; GRATÃO, 2010).

Now, if an image is the result of the eye of the person who creates it, imagines it and its meaning is a consequence of the interpretation given by the viewer, observer or the spectator, then the pictorial-poetic image of the Das Contas River is a result of our way of looking at the river and according to Ferraz (2009), it is this look of the observer/creator that interests [Humanist] Geography. On the humanist perspective of Geography, Chiapetti and Gratão (2010) write that it is a science that has the possibility of meeting with art, through its categories of analysis, contained in their poetry or in any type of artistic representation, such as an image, for example. These are "new" (or not so new) ways of understanding space and interpreting the culture expressed through language and/or image, created by authors and artists. A humanist geographer must, among other things, awaken our awareness that we are responsible for our geographic space and that we must reflect critically on it, by different means (art may be one of them). Therefore, in this text we carried out, with sensitivity and knowledge of reality, the analysis and interpretation of the image (in this case, pictorial or artistic) that represents the Das Contas River and its phenomena, with human life represented in its landscape.

An image can represent what we perceive, know, feel, yearn, imagine, dream, live, experience, think, write, discuss... Reading and analyzing an artistic image can be a way of aesthetically reflecting on that place, that landscape (world view), because we can read and interpret this image and, from it, get information, knowledge about the place, about the world. But, like all non-verbal texts, it allows several interpretations of its signs or drawings; it is the way we grasp its meanings that will reveal our reading of the image. Between the image and the reality that it represents there are many factors that can guide our reading, so everything depends on our knowledge of reality, the cultural conditions, perception, imagination, feelings... for the image to be a true reconstruction of reality.

The understanding of the aesthetics and poetics of the pictorial-poetic image of the Das Contas River leads us to a reflection on the course of the river, on its river basin, from our knowledge of the reality of the river. Of course, in addition to geographic knowledge, sensitivity is needed to understand the context in which this image was created. Thus, the artistic and sensitive aesthetic interpretation of this image reveals our emotions regarding the river. Its reading and analysis are ways of understanding the river and its real banks and aesthetically offering information as if it were a language, that is, a visual or non-verbal text.

This pictorial-poetic image illuminates our words, giving them poetic sense, as it also adorns our "river-friend." We give ourselves the right to call it that, since in the time in which we have researched and experienced it, we have come to know it beyond its physical form, knowing its essence. This is how the Das Contas River presents itself in this image/language. Our intention in this text is not to conceptually analyze the pictorial-poetic image within the notions of semiotics, but rather to improve our geographic reading of the river, poetically, as Ferraz (2009) writes, through aesthetic and sign analysis, toward an interpretation of the landscape from its pictorial representation.

This pictorial drawing of the Das Contas River is a fixed image, stopped in time but able to represent its landscapes. The main forms of occupation of the banks of the river are represented by figures or symbols expressing ideas, that is, the figurative and stylized drawing (a figure for each object) functions as a sign (symbol) of writing. It is as if a text on the Das Contas River was written in the form of a drawing, attributing a universal intelligibility to it, like a photograph. For Pinheiro 
(2000), photography is a subjective, emotional look that interprets cuts, selects and chooses; but also, it is the look of the enthusiast, with their culture, emotion and life history. Photography is still an indirect text, in which one can hide, beyond the image, in the imaginary.

When we look at the image, the Das Contas River emerges as if it were born in the background (in the west), in the mountains of the Chapada Diamantina, distant in the image, another landscape and winding with the movement (energy) of its waters, it symbolizes the life on its banks, until reaching its destination, in the foreground of the image (in the east), when it ends in the sea, in front of the city of Itacaré, on the south coast of Bahia. Also we can imagine a river that rises on the top of the mountain (1,500 $\mathrm{m}$ of altitude), descends... symbolically telling all the adventures of life in the sertão... and enters the forest to meet the sea. In this way, the river serves as a representation of human life wherever it passes, since its water kills thirst and hunger, washes, leads, produces energy, entertains... it is human survival itself!

In this pictorial-poetic image we are poetizing the Das Contas River. To poetize is to say what could not be said otherwise, it is to seek words in silence; it is to draw from its image and landscape the inspiration to compose a song, write a poem, make a drawing, a painting or simply art, besides imagining, dreaming, daydreaming or thinking about reality. We agree with Bosi (2006, p. 75): "The truth of art is a truth of body and soul" and therefore any artistic expression can be a direct way to reach people's understanding of what we want to express because it is a universal language, which can be understood by different cultures, promoting dialogue, reflection, an encounter between them. To poetize is also to delight in this image of the Das Contas River, which creates a kind of poetic narrative about it, represented in the blue of the water and in the shades of colors of its banks between (the Brazilian) green and yellow, going from the green of the mountains, through the semi-arid yellow sertão and gradually, in a transition area, becoming greenish yellow, until it reaches the green Atlantic Forest.

Furthermore, we can interpret this pictorial-poetic image, reflecting on the river that is born in a "green oasis" within the "yellow sertão of Bahia", contributing to the living conditions of the Chapada Diamantina's population (tourist activity in the mountains and agriculture on the valley floors). Then, in the "yellow Caatinga", it continues donating life to agriculture, goat breeding and electric energy production, to return to being "green in the Atlantic Forest", its most populous stretch, affectionately known as the Cocoa Region of Bahia (a region that still produces cocoa, a great wealth of Brazil), and finally to empty into the calm Concha beach, in the city of Itacaré, heavily frequented by Brazilian and foreign tourists.

The colors are very important in this poetic of the river, they are like elements that sustain the landscape, contrasting with the blue of the water, which seems to flow through by the image and in reality producing electric energy (Pedras Hydroelectric Plant, in Jequié), connecting the three biomes, crossing two large Brazilian highways (BR 116 and BR 101), linking cities in Bahia (Juciape - Jequié - Ubaitaba - Itacaré), passing through Taboquinhas district (municipality of Itacaré), when the river narrows into a canyon and finally meeting the sea, or turning into the sea!

The symbolic value of the colors represented in the pictorial-poetic image goes through the life of the river itself, born in the touristic Chapada Diamantina, from beautiful landscapes, surviving in the long-suffering Caatinga of the sertão, of the Mandacaru cactus and the goat, but also produces beautiful landscapes (depending on the eye), experiencing the coastal tourism of Bahia, of green forests, crystalline rivers and wonderful beaches. We can affirm, according to Gratão (2007a, p. 103): "It is 'The river' perceived through the look, by the senses, sensations, in what is 'visible' in the 'not visible'; in the shift...in movement ... in color... in the smell... in sounds \& tones... 'The river' evoking feelings, emotions, memories, evoking the Spirit of the place...".

In short, this image of the Das Contas River, from the Chapada to the Ocean, is the river itself in its essence ... a river with water, with banks, with curves, with life... that is born, that flows, that provides life , that arrives at its destination...and, that fulfills this destiny. 


\section{THE RIVER ... DRAWING ITS LANDSCAPES}

The geographic landscape is not, in its essence, only to be contemplated, but refers to the insertion of people in the world, a place of life, a manifestation of their being with others, the basis of their social being (CHIAPETTI, 2009). Therefore, landscapes presuppose the presence of people, even when they are physically absent, because they express their fulfillment and existence on Earth. Thus, we can affirm that the landscapes of the Das Contas River represent the experiences of the people who have passed through, inhabited and inhabit its river basin. They are, therefore, lived landscapes, in which the relations of people with their place are evident, being substrates of their experiences in the river. For Besse (2006), the landscape is the expression of existence, being a bearer of meaning, because it represents the encounter between the Earth and society. It is essentially more of a human world than natural. It is culture as the meeting of human freedom with its place, the Earth.

The landscape is the representation of what we see, however, vision is only the sensation of what we perceive, evidence of the invisible. Thus, when trying to represent what we perceive and which is often invisible, we use symbols. Therefore, a landscape can be symbolic, representing the expression of the multiple senses that we confer to our environment. Yázigi (2001) also writes about the symbolism of landscapes, saying that they have expressively symbolic attributes, which leads us to consider that the natural beauties of the Das Contas River are some of its symbols and therefore represent some of their landscapes.

The landscapes of the Das Contas River are the result of historical processes, representing different moments of the societies that inhabited its river basin. It is as if it were pouring into its banks the landscapes that have been transported in its waters since time immemorial, becoming a memory of the history of Bahia and, perhaps, of Brazil. As an example, in the Chapada Diamantina its landscape has marks of the gold and diamond exploration of the past and in the Atlantic Forest the landscapes are of cacao farms, which historically keep producing in the same way. The beautiful and difficult reality that moves and shelters on the banks of the Das Contas River presents itself, not merely as landscapes represented in a pictorial-poetic image, but as an inseparable part of the whole, which constitutes the essence of its river basin, human sensitivity (or not), the mysteries of life, in short, the lives of the people who inhabited and still inhabit the banks of this river, building their landscape and their identity. For Gratão (2002) these are landscapes described and internalized in feelings, registering intimacies and guarding perceptions and significant experiences.

The landscapes keep the intentions and actions of the people in the places, because they are marks imprinted on the original landscapes and events are recorded over time, considering different natural and cultural factors. Therefore, landscapes are the result of a succession of intricate superimposed factors, which are registered in the individual and collective memory of society, becoming powerful elements of cultural identification, which are constantly being updated.

So, in order to analyze a landscape or, in this case, the landscapes drawn along the Das Contas River, in addition to the natural and human elements it is necessary to understand the meaning of this river in Bahia's history and the history of the river itself, geared towards the people who produced/constructed/experienced its landscapes. These landscapes were experienced by native people, slaves, miners, European explorers, Portuguese settlers, foreign pirates-thieves, sugar cane planters, inhabitants of the villages and after the small towns that formed along the banks, cacao growers, ferrymen, boatmen, fishermen, seafood fishers, laundrywomen, escaped slaves, tourist guides, rafting instructors, tourists, athletes, poets, thinkers... landscapes experienced by people who have built and continue to build the identity of the river.

We ask, then, what are the landscapes of the Das Contas River and what landscapes are represented in the pictorial-poetic image of this river? Well, let's start with the landscapes of its source, the landscapes of the Chapada Diamantina mountains. How beautiful ... it's breathtaking! The Pai 
Inácio Hill (the largest in the image), besides being aesthetically beautiful, there are no words to explain the sensation we feel when we are up there. Perhaps the feeling of belonging to nature, being nature itself, or perhaps being so small near such greatness! The Tromba mountain range (the river's source), on the west side of the Chapada Diamantina, is considered to be one of the most preserved in the state of Bahia. The whole drainage network of this mountain enters the Das Contas River, which is born in the extreme south of the municipality of Piatã.

The landscape of the Chapada Diamantina can be geomorphologically identified, according to Brasil (1981) as an old and worn relief, with mountains, dissected plateaus that stand out, carved by water and wind, cut by deep valleys of rivers. This landscape was formed thanks to millions of years of erosion because as some sedimentary rocks are more compact and others more permeable, that is, easier to be infiltrated by water, with the passage of time some resisted, others were more worn down. Sandstone, for example, is more resistant to water action and has resisted in the higher altitudes. The cracks in the rocks facilitated the infiltration of water, and thus, the less resistant ones were eroded, with the aid of climatic variations.

According to the Brazilian Institute of Geography and Statistics (IBGE, 1960), the Chapada Diamantina area (like the entire northeastern sertão) was subject to a series of diverse morphoclimatic systems. Initially, there was a wet period when the valleys were carved out and the inversion of the relief began. Subsequently, the climate became drier, the granitic rocks were removed more quickly and the sandstones and limestones became more prominent. Due to the dry climate, the inter-mountain plains and sediments of fine limestone, known as calcareous Caatinga, were extended. These sediments are evidence that the area was subject to alternating climates.

When the weather became more humid, the rivers began to carve their beds in the limestone. However, when another dry phase began, they started to be clogged again by deposits brought about by the action of rainwater. This climatic alternation occurred in the Pleistocene and Holocene geological periods (IBGE, 1960). The climatic oscillations of the Pleistocene affected all the old surfaces, introducing alterations in the evolution of the slopes, so that it is possible to glimpse several morphoclimatic systems in the Chapada Diamantina. In order to explain the evolution of the Chapada Diamantina's landscape we must understand that its formation took place in distinct processes and occurred in times geologically very far apart (BRASIL, 1981).

In relation to the human occupation of its river basin Jorge (2006), when writing that the Das Contas River, with its tributaries, amid hills, sertão, forests and mangrove swamps, gave Bahia's lands a truly charming aspect, with an environment conducive to the establishment of human settlements, as the physical conditions, flora, fauna and water provided people with an opportunity for subsistence. Like many other rivers, the Das Contas River certainly had great importance in the beginning of the towns that gave origin to the cities located along its route. It was from this that the exploration of gold advanced in the sertão of Bahia, settlements emerging and roads being built in the region nowadays occupied by the Chapada Diamantina (TEIXEIRA, LINSKER, 2005).

In the pictorial-poetic image of the river, Jussiape is the city that represents the urban landscape in the Chapada Diamantina area, a municipality with intense tourist activity. Officially, the municipality of Jussiape is included in the gold circuit, possessing a historical landscape preserved by folk customs and traditions, as well as the beauties of the landscapes, such as the Serra da Itobira and the former gold mines of Pedro Silva and Beta da Tavinha. There are also significant archaeological sites, such as the unpublished pictorial representations of the Serra da Tapera and the cave paintings of Espinho (http://www.bahiaemfoco.com/jussiape).

Continuing the river's landscapes, we reach Bahia's semiarid sertão, which according to the Superintendency of Economic and Social Studies of Bahia (SEI, 1994) has a relief composed of Peripheral and Interplanaltic Depressions and the South-Baiano Plateau. For Brasil (1981), this relief corresponds to the domain of the Interplanaltic Depressions, which occur in a wide depressed area between the Chapada Diamantina and the South-Baiano Plateau, with reliefs evolved on highly 
metamorphized rocks or areas of crystalline shells, which are characterized by being subjected to intense removal and where morphoclimatic influences predominate on these structures.

For Conti (2002), the landscape from the semi-arid climate, with its lithological and geomorphological characteristics, is very particular, mainly due to the presence of the vast Caatinga, formed by dry shrubs, cacti, bromeliáceas and trees of rare beauty, like the umbuzeiro (Spondias tuberosa). The cactus named Mandacaru, is an important symbol of Bahia's sertão and was therefore represented in the pictorial-poetic image of the river, in addition to goat breeding, which also composes its poetic landscape (pastures for breeding goats - the largest flock - predominate in the Caatinga). The symbolic content of the landscapes can be used to create touristic images, which, in the case of Bahia's sertão are very well represented by these elements or symbols, that is, cacti and goat breeding.

Within this domain the Das Contas River, does not have a large volume of water, due to the rigors of the semi-arid climate, with an absence of rain for most of the year and with water loss by evaporation. Another factor that contributes to the dry landscape of the river is that in the municipality of Jequié it was dammed to control floods, supply water, agricultural irrigation and electric power generation, according to the São Francisco Hydroelectric Company (CHESF). It now flows slower in a large lake (approximately $70 \mathrm{~km}$ long and 38,700 km2), gaining strength and power to generate the turbines of the Pedras Hydroelectric Plant, since 1969 (www.chesf.gov.br). After this intervention in the river's course, its waters were controlled by people, who have power over the life of the river (releasing more or less water in the spillways of the great lake) and only then can it become once more a humble river flowing downstream... in search of its bed. It is important to remember that even with all the controversy about the installation of a hydroelectric power plant, the Pedras dam's lake in Jequié enchants many people, who use it for fun, fishing, sports, inspiration, contemplation... another landscape!

Like the Chapada Diamantina, the Das Contas River played an important role in the human occupation of Bahia's sertão. In the relation that the sertanejo establishes with the river, there is an entire relationship of the exchange of survival between them and the river itself, in the way of feeling it, using it and experiencing it. As an example Jequié, the largest municipality on its banks, is considered to be the mouth of the sertão, because it is located in the transition area between the sertão and the forest. As it was formerly more voluminous and narrow and therefore navigable, the Das Contas River was the main transportation route for the products necessary for the subsistence of the local inhabitants, such as: cereals, vegetables, fruits, greens and some industrialized products. Thus, Jequié developed from a lively market (a tradition of northeastern culture) that attracted people and merchants from all over the region.

Finally, to end our trip through the waters of the Das Contas River, the landscape of the Atlantic Forest comprises the South-Baiano, Pre-Coastal and Coastal Plateaus. These plateaus cover mountainous reliefs with mountainous features, interspersed with relatively flat areas, with decreasing altitudes to the coast (BRASIL, 1981). According to Brasil (1981), within this biome, in the vicinity of the river mouth, in the geomorphological domain of the Coastal Plain, there are Marine and Fluvial-marine Plains, which have marine, fluvial, colluvial and eolic origins that translate the stages of evolution of the coast and the lower courses of the rivers. Along much of its extension in this landscape the Das Contas River is bordered by the remnants of the Atlantic Forest in its secondary phase, which follows the gliding of the river, sometimes slow or fast in the rapids of the district of Taboquinhas (Itacaré municipality). The trees in this area are large and harbor a rich and diverse fauna.

On its journey through the forest, the Das Contas River is dammed again for its waters to move the turbines of the Funil Hydroelectric Plant (operating since 1962), in the municipality of Ubaitaba, in the south of Bahia. The walls of this dam imprison it, again, forming a small lake of approximately $4 \mathrm{~km} 2$ (www.chesf.gov.br). It is a landscape experienced by the people of the place 
who suffer the loss of the river and the Funil waterfall, which was submerged with the construction of the reservoir. For Ferreira (2001, p. 100): “At that time, only the region's progress was taken into account and environmental protection was forgotten. The plant was built and given the name of 'Funnel Hydroelectric Plant', after the waterfall. It is just as well they remembered this tribute!' Thus, future generations will know that there is a beautiful waterfall submerged in the waters of the Funil dam. This same author explains that the waterfall was formed by three large stones that together resulted in a huge crater in the form of a funnel; hence the origin of its name. When the Das Contas River had little water, the stream passed under the stones, giving the impression that the waters disappeared into the earth, only to flow into the sea, much later.

In the Atlantic Forest area of southern Bahia, the Das Contas River was one of the great motives for the beginning of settlement, being the shelter/home of the native people who inhabited the region before the arrival of the Europeans and the waterway of the Portuguese in search of the interior of the Continent, as well as a refuge for fugitive slaves. In this section, the Das Contas River represents a link between the cities of Jequié, Jitaúna, Ipiaú, Barra do Rocha, Ubatã, Aurelino Leal, Ubaitaba and Itacaré, since all are blessed with its water, but they are also responsible for life of the river, for its landscapes. Everything that is done in one city comes to the other... it is water connecting lives. But unfortunately, in this region the river shows signs of pollution due to the waste dumped in its waters by the population of these cities, even though the Superintendence of Water Resources of Bahia (SRH/BA) does not prove this fact, because, according to this state body, the river is only polluted in the vicinity of the city of Jequié, in the transition from the Caatinga to the Atlantic Forest.

On the river flowing and full in this landscape there is only longing, like that of the poet Fuad Maron, who with sensitivity and beauty sings, in his poem, the Das Contas River of Ipiaú.

Das Contas River, root of my longing

When the sunlight seeps

The dark sky appears

Then the water descends,

Fills the river, and the heron flies ...

While rowing, the canoe dances,

The hopeful boatmen

Cast their nets in the water,

While it flows out

The river runs, narrows and passes

Foaming past the huts

Under a beautiful indigo sky

Racing through the funnel

And then galloping to the sea.

From Jequié is flows full

The river kissed the sunset

Reflected on the flush

Today cut in half ...

It was beautiful, today it's so ugly.

It moves a soft clay 
Nothing else moves in it

There are no ferries and canoes! ...

The Kingfisher no longer flies

The long-tailed tyrants and herons have left...

The Water Rail in other places

Oh! My river, I missed you for nothing.

Far away today, I reap an aurora.

The Das Contas River at six o'clock

Receives a kiss from the breeze

Singing birds are heard

Warbling on your banks

When the sun extinguishes its skirt

At night which garland is seen

In the white silver moonlight,

And the coconut palm fronds

Are vigilant warriors

Where the fisherman is hiding

And in other trees with fronds

And in the tawny sandbanks.

Das Contas River from my city

Your sands are so white.

You are the root of my longing,

You run in my veins.

Source: Maron (1997).

On the other hand, in Itacaré, the last municipality that it bathes the Das Contas River offers its waters and landscapes to tourism, which is the means of survival for a large part of the population, corroborating Gratão (2007b), for whom throughout the world water has attracted tourism, more and more desired and sought after - adventure, cultural and religious tourism. It is the presence of the turbulent and calm water of the river, the mountains, the Atlantic Forest (still with conserved areas) and also the local characteristics of the sea that become attractive for regional, national and international tourism. In the course of the Atlantic Rainforest within the territory of Itacaré, the landscapes of the Das Contas River are marked mainly by adventure tourism in its waters, as it winds snake capriciously through ravines, forming rapids (stretches of rivers, where the waters are faster), a canyon (narrower river) and the last waterfalls from its bed, the waterfalls of Fumo and Pé da Pancada, in the district of Taboquinhas.

The Pé da Pancada waterfall is represented in the pictorial-poetic image of the river, responsible for a remarkable landscape in the history of the region, because as it is the last waterfall it is told that having transported the crop by land, Cocoa farmers loaded their boats with all the cacao produced on their farms by the river, to be transported to the sea and taken to the Port of Ilhéus (further south). Even today, when we talk to some people in Taboquinhas (in front of this waterfall) they tell this story from their memories, because this region was a big producer of cocoa and this part of the river was responsible for taking its wealth to its destination (outside the country). We can even imagine these boats (called Gasolines), packed with this beautiful yellow fruit, transported as if it were gold (that's why it was called the golden fruit), gliding along the navigable $25 \mathrm{~km}$ of the 
river, until it reached the sea. It is one of the river's landscapes, a landscape humanly registered in its waters and in the memory of the people of Taboquinhas! It is incredible how we imagine this landscape experienced by the people of the river, when we know the village of Taboquinhas and its history! In fact, there is still the stone road that carried the carts loaded with cacao to its right bank.

Another landscape of the Das Contas River, within the Atlantic Forest, is the practice of extreme sports, mainly by tourists. The waters agitated by rapids (they serve as paths for the practice of sports) and the narrow banks of the canyon are conducive to rafting (represented in the image by a boat carrying people by the waters of the river, in Taboquinhas). This is a type of sport practiced in rapids and small river waterfalls using inflatable boats and oars, in which the practitioners must use helmets and life jackets. Rafting is a symbol of the river's landscape in the district of Taboquinhas, since it is a tourist landscape greatly promoted by the regional media and experienced by domestic and foreign tourists.

Also in its last stretch, the Das Contas River lives and at the same time is the location of the beautiful landscape of speed canoeing, a sport practiced mainly in the riverside cities of Ubaitaba (called Bahia's canoeing capital) and Itacaré. This sport impresses by the beauty of the canoes skimming gently through the water... as if the canoeists were gliding over the river... competing with the speed of the water or mingling with it!

The river, in its heroic adventure through Bahia, finally finds its destination, with the certainty of a duty fulfilled, that is, to carry water in its river bed, mixing it with the sea of the immense Atlantic Ocean! The last landscapes of the river are recorded in its estuary and in its pictorial-poetic image: fishing boats arriving from work at sea, canoes or boats for touring the waters of the river, the urban tourist life of Itacaré, Concha beach and the Barra Lighthouse, which daily witness the encounter of the river with the sea, when the river turns to sea.

Before finishing this text, besides the essence of the river, we would like to write about its agony, that is to say, about the death of the Das Contas River in the stretches in which some cities, mainly Jequié and some on the lower river, in its most populous stretch in the Atlantic Forest. Even if this is not drawn in its pictorial-poetic image, the real landscape represents the sad image of reality and does not hide this sadness! These are the waters of the Das Contas River in the south of Bahia, traversing many cities and carrying the pollution poured into its bed, without blame for those who do so.

We need rivers so much and why do we mistreat them so badly?! Are not we dying along with our rivers?! If water commands the earth, it commands life, it is the life of the earth, how can we mistreat it, polluting it? What will the fate of the Das Contas River in a while? We have no answers to these questions but with this text we want people to reflect...

We ask, then, does the Das Contas River still exist? The jequieense poet Daniel Gomes de Souza Júnior, in his poem "There is a river", writes about the importance of this river in the past, a river that today is abandoned and with an uncertain existence in the future.

There is a river

There is a river that in the past has been explored, sucked dry.

Today there is an abandoned river,

Dirty, almost finished.

The past remembers the river with longing;

This river that crosses several cities

Traversing rafts, canoes 
People who look at the river without affection,

Without looking at the concrete... the river and its uncertain future.

Without knowing if one day... we can call the poem: there is a river or There was a river

Source: www.webartigos.com/articles/22272/1/RIO-DE-CONTAS/pagina 1 . html\#ixzz1KjCJ91z8.

The social death of the river, as the anthropologist Leonel (1998) writes about the relations of society with nature, which are inseparable from the relationships that men maintain among themselves. Regarding the relationship we have built with the Earth, Gratão (2007a) invites us to change our thinking and attitude, since we have become the owners of natural resources, not respecting our natural and cultural ties with the Earth. A new way of looking at the world starts from fundamental changes in our thoughts, perceptions, attitudes and values. We must reflect!

\section{FINAL CONSIDERATION}

Reflection... we hope that we have succeeded in providing a geographic-humanist reflection in this text, a poetic essay, conducted by the waters of the Das Contas River, through its pictorial-poetic image, representing the landscapes lived by the people of its river basin and described by our perception. We refer to a geographic-humanist reflection because we place human beings as the object of scientific knowledge, since the landscapes are constructed and lived by them.

Through phenomenology, a theoretical-methodological proposal that led to our analysis, it was possible to interpret, describe and understand, with great sensitivity, the course of the Das Contas River from there to here ... drawing its landscapes, empowered by our experience and geographical knowledge. Phenomenological research starts from the understanding of living and not from definitions or concepts, being an understanding directed at the meanings of perceiving, which shows itself and in itself as it is. Thus, this focus, approach or methodological attitude, considered by many to be unusual, proved to be valid in our work, considering that we could understand what was manifested, what was actually shown in the landscapes constructed by the people of the river.

The pictorial-poetic image had the role of representing in an artistic and aesthetic way our emotions in relation to the Das Contas River, since art is a way of manifesting / living the poetic quality of life. Thus, signs, symbols or figures represented our perception or geographical interpretation of reality and also how we perceive the meanings of the landscapes that were pictorially represented, or rather, how we poetically portrayed our knowledge of the geographic reality of the river.

Finally, our main objective was reached, since we intended, with the elaboration of this poetic essay on the Das Contas River, to make a geographical reading towards the interpretation and analysis of its landscape, from its pictorial representation. All the landscapes drawn by the river in the image and registered in its waters and margins are real demonstrations of the people's connection with "their river", of the experience of the being in the world, their lived space. The river, along its path (green, yellow and green again), carries the landscapes of the touristic Chapada Diamantina, of the distant sertão of Bahia, the green Atlantic Forest and the beautiful southern coast of Bahia, recording the experiences, intentions and actions of people in the river-place. The pictorial-poetic image is, therefore, a physical and poetic-cultural construction of the Das Contas River of Bahia. 


\section{BIBLIOGRAPHIC REFERENCES}

BACHELARD, Gaston. A água e os sonhos: ensaios sobre a imaginação da matéria. São Paulo: Martins Fontes, 2002. 202 p.

BACHELARD, Gaston. A poética do espaço. São Paulo: Martins Fontes, 2005. 242 p.

BESSE, Jean-Marc. Ver a terra: seis ensaios sobre a paisagem e a geografia. São Paulo: Perspectiva, 2006. $108 \mathrm{p}$.

BOSI, Alfredo. Fenomenologia do olhar. In: NOVAES, Adauto (Org.) et al. O olhar. São Paulo: Companhia das Letras, 2006. p. 65- 87. 495 p.

BRASIL, Ministério das Minas e Energia, Secretaria Geral. Projeto RADAMBRASIL. Folha SD 24 Salvador: geologia, geomorfologia, pedologia, vegetação e uso potencial da terra. Rio de Janeiro, 1981.

CHEVALIER, Jean; GHEERBRANT, Alain. Dicionário de símbolos: mitos, sonhos, costumes, gestos, formas, figuras, cores, números. Colaboração de André Barbault et al. e coordenação de Carlos Sussekind. 21. ed. Tradução de Vera da Costa e Silva et al. Rio de Janeiro: José Olympio, 2007. 996 p.

CHIAPETTI, Rita Jaqueline Nogueira. Na beleza do lugar, o rio das contas indo... ao mar. 2009. $216 \mathrm{f}$. Tese (Doutorado em Geografia) - Instituto de Geociências e Ciências Exatas, Universidade Estadual Paulista Júlio de Mesquita Filho, UNESP, Rio Claro, São Paulo, 2009.

CHIAPETTI, Rita Jaqueline Nogueira; GRATÃO, Lúcia Helena Batista. A poética n’as curvas do rio: a imaginação geográfica no rio Cachoeira. Geografia, Rio Claro, v. 35, n. 2, p. 275-289, maio/ago. 2010.

CONTI, José Bueno. A natureza nos caminhos do turismo. In: RODRIGUES, Adyr Balastreri (Org.). Turismo e ambiente: reflexões e propostas. 3. ed. São Paulo: Hucitec, 2002. 177 p. p. 17-26.

DARDEL, Eric. O homem e a Terra: natureza da realidade geográfica. São Paulo: Perspectiva, 2011. 159 p. FERRAZ, Claudio Benito Oliveira. Geografia: o olhar e a imagem pictórica. Pro-Posições, Campinas, v. 20, n. 3, p. 29-41, set./dez. 2009.

FERREIRA, Ivan Estevam. Ponte do Cristal. Vitória da Conquista, BA: Edições UESB, 2001. 224 p.

GRATÃO, Lúcia Helena Batista. A poética d" "O rio" - ARAGUAIA! De cheias... \&... vazantes... (à) luz da imaginação! 2002. 354 f. Tese (Doutorado em Geografia Física) - FFLCH, Universidade de São Paulo, USP, São Paulo, 2002.

GRATÃO, Lúcia Helena Batista. (À) Luz da imaginação! "O Rio" se revela na voz dos personagens do lugar-ARAGUAIA! Caderno de Geografia, Belo Horizonte, v. 17, n. 28, p. 89-120, $1^{\circ}$ sem. 2007a.

GRATÃO, Lúcia Helena Batista. A água no fluxo do turismo - do elemento essencial ao destino do turista... convite ao lazer, prazer, ócio, hierofonia, sonhos e imaginação! In: SEABRA, Giovanni. Turismo de base local: identidade cultural e desenvolvimento regional. João Pessoa: Editora Universitária da UFPB, $2007 b$. 356 p. p. 51-64.

HOLZER, Werther. Uma discussão fenomenológica sobre os conceitos de paisagem e lugar, território e meio ambiente. Revista Território, Rio de Janeiro, n. 3, p. 77-85, jul./dez. 1997.

IBGE. Instituto Brasileiro de Geografia e Estatística. Enciclopédia dos municípios brasileiros. Rio de Janeiro: IBGE, 1960. Vol. V.

JORGE, Janes. Tietê, o rio que a cidade perdeu: o Tietê em São Paulo - 1890 a 1940. São Paulo: Alameda, 2006. $232 \mathrm{p}$.

LEONEL, Mauro. A morte social dos rios. São Paulo: Perspectiva; Instituto de Antropologia e Meio Ambiente; FAPESB, 1998. 263 p. (Coleção Estudos, 157).

LESSA, Gabriela. No baixo São Francisco, a viagem do redescobrimento: do espaço ao lugar. Niterói, RJ, 2007. 167 f. Dissertação (Mestrado em Arquitetura e Urbanismo) - Universidade Federal Fluminense, UFF, Niterói, RJ, 2007.

MARON, Fuad. Os canoeiros do rio das Contas. Salvador: Graficartes, 1997. 117 p.

MELLO, Thiago de. Amazonas, pátria da água. Rio de Janeiro: Civilização Brasileira, 1987. 112 p. 
OLIVEIRA, Lívia de. Sertão rosiano: percepção, cognição e afetividade geográfica. Scripta, Belo Horizonte, v. 5, n. 10, p. 234-242, $1^{\circ}$ sem. 2002.

PINHEIRO, Jane. Antropologia, arte, fotografia: diálogos interconexos. Cadernos de Antropologia e Imagem, Rio de Janeiro, UERJ, v. 10, n. 1, p. 125-35, 2000.

SEI. Superintendência de Estudos Econômicos e Sociais da Bahia. 1994. Disponível em: <http://www.sei. ba.gov.br/>. Acesso em: maio 2013.

TEIXEIRA, Wilson; LINSKER, Roberto (Coords.). Chapada Diamantina: águas no sertão. São Paulo: Terra Virgem, 2005. 160 p.

YÁZIGI, Eduardo. A alma do lugar: turismo, planejamento e o cotidiano em litorais e montanhas. São Paulo: Contexto, 2001. 301 p. 